\title{
当科において腹腔鏡下手術を施行した妊娠合併卵巣腫瘍症例25例の検討 Treatment of 25 cases of ovarian tumor during pregnancy by laparoscopic surgery
}

岐阜県立多治見病院産婦人科 竹田明宏、真鍋修一、細野覚代、中村浩美

\section{はじめに}

近年、腹腔鏡下手術手技の進歩や手術機器の開 発改良により、腹腔鏡下手術の適応は拡大しつつ ある。妊婦に対する腹腔鏡下手術の適用は ${ }^{11}$ 、低 侵襲性手術であることにより早期離床が可能であ る等の利点はあるものの、麻酔や手術手技が及ほ す胎児への影響についての評価が定まっていなか ったために、比較的禁忌とされてきた。しかしな がら、近年、妊娠期間中に、腹腔鏡下手術が行わ れた例が、外科領域においては胆囊摘出術 $\left.{ }^{2}\right)$ や虫 垂切除術 ${ }^{3)}$ 等で、婦人科領域においては卵巣腫瘍 手術で報告されるようになり 4-12)、その安全性が 確立されつつある。

また、近年は、経胵超音波断層法等の診断技術 の進歩により妊娠初期に卵巣腫瘍が発見される例 が増加してきている。妊娠に合併する卵巣腫瘍に おいては、悪性腫瘍の頻度が低いと報告されてい ることからも ${ }^{13,14)}$ 、卵巣腫瘍を合併した妊婦に対 する腹腔鏡下手術は、その適応や手術時期を慎重 に決定するとともに、手術操作が安全に行えるな らば、術後QOL向上に寄与するものと思われる。

当科においては、以前、 8 例の妊娠合併卵巣腫 瘍に対して、皮下鋼線吊り上げ法による腹腔鏡下 手術を行い、母児に対する安全性につき検討し、 その結果を報告しているが99、今回、更に症例を 重ね、25例の妊娠合併卵巣腫瘍に対して全身麻酔 下に皮下鋼線吊り上げ法による腹腔鏡下手術を行 い、その適応、手術を行う最適な週数ならびに術 後経過から見た安全性等につき検討したので報告 する。

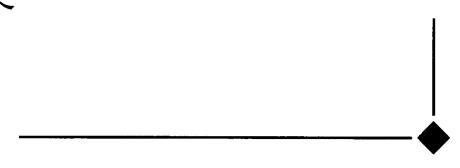

対象と方法

1997年5月から 2002年10月までに当科で腹腔鏡 下手術を行った1198例中、妊娠合併卵巣腫瘍25例 を対象とした。手術適応は、腫瘍径が $5 \mathrm{~cm}$ 以上 のもの、ダグラス窩にあって分婏障害となる可能 性のあるもの、腹痛等の自覚症状のあるもの、超 音波断層法やMRIでの画像上から良性腫瘍と診断 したものとした ${ }^{9)}$ 。黄体囊胞や内膜症性囊胞と考 えられる症例は、強い腹痛等の自覚症状がない限 り保存的に経過観察する方針とした。腫瘍マーカ 一值はCA125、CA19-9、CEA、AFP、SCC、 CA72-4を計測したが、異常值を示した例におい ても、画像所見を重視し、画像上、良性腫瘍と考 えられた場合には、腫瘍マーカー値の異常は参考 所見にとどめた ${ }^{15)}$ 。手術を行う週数は、黄体囊胞 の除外が可能で、かつ、胎盤の完成により妊娠が 安定してくる12週前後としたが、患者の初診時期 により16週までは手術を行った。妊娠16週以降に 受診してきた症例においては、腹痛等の症状がな い限り、帝王切開術が必要となる可能性を含めた 今後の見通しや捻転、破裂等の考え得る妊娠中の 合併症の可能性につき十分な説明を行った後に、 基本的に経過観察とした。

麻酔は、当初は脊椎麻酔 (一部、硬膜外麻酔併 用）で行っていたが、術中、腸管への鉗子の接触 刺激により嘔吐が誘発され、視野確保が困難とな り、術中に全身麻酔へ切り替える場合も多かった ことから、現在は、最初から気管内抻管による全 身麻酔下に手術を行っている。腹腔鏡下手術は、 皮下鋼線吊り上げ法により行った ${ }^{16)}$ 。臍下正中皮 下に刺入した $1.5 \mathrm{~mm}$ キュルシュナー鋼線を固定し た吊り上げハンドル（瑞穂医科工業、東京）を把 
持することにより、腹壁を挙上しながら、臍上部 の臍縁縦切開創より、 $5 \mathrm{~mm}$ オプティビュウ（ジ ョンソン・エンド・ジョンソン、東京）を直接穿 刺した。この際、腫大した妊娠子宮を損傷しない ように十分注意した。 $5 \mathrm{~mm}$ 腹腔鏡（オリンパス、 東京）による腹腔内観察の後に、臍左側に $5 \mathrm{~mm}$ オプティビュウを留置した。体外法での襄腫核出 あるいは付属器摘出術を行う場合には、䎵骨上1 横指の位置に1.5-3cmの横切開を加えた後に、

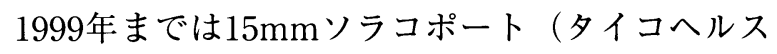
ケア、東京）を、2000年以降はラッププロテクタ ーミニ (八光商事、東京)を留置し手術を行った。 体内法で付属器摘出術を行う場合には、臍右側に $12 \mathrm{~mm}$ オプティビュートロッカー（ジョンソン・ エンド・ジョンソン、東京）を留置した。自動縫 合器により勒帯を切断し、エンドポーチに収納後 に $12 \mathrm{~mm}$ 処置孔より体腔外へ搬出した。自動縫合 器は、エンドカッター35mm（ジョンソン・エン ド・ジョンソン、東京）を用いた。また、癒着剥 離が必要な場合には超音波メス、ハーモニックス カルペル（ジョンソン・エンド・ジョンソン、東 京）を使用した。妊娠合併卵巣腫瘍においては、 術中、腫瘍がダグラス窩に陥頓しており、更に、 腫大した妊娠子宮が物理的に障害となり、腫瘍を 挙上することが困難な例を、しばしば経験する。 このような場合には、経腟的に後腟円蓋部を示指 により上方へ押して、ダグラス㝑から腫瘍を上方 へ押し上げながら、腹腔鏡下での把持鉗子と協調 させながら、腫瘍を膀胱子宮窩に移動させた後に 手術を行った。囊腫内容を穿刺吸引する必要があ る場合には、内容漏出を防止する目的でサンドバ ルーンカテーテル (八光商事、東京)を用いた。 手術術式は、囊腫核出術を基本としたが、経産婦 で本人の付属器摘出術希望がある場合や囊腫核出 術が困難等の条件により付属器摘出術も行った。 腹壁創部の閉鎖は、3-0吸収糸による皮下埋没縫 合と皮膚接着剂ダーマボンド（ジョンソン・エン ド・ジョンソン、東京）により行った。子宮収縮 を予防する目的で、手術前から、術後 2 日目にか けて、塩酸イソクスプリンの筋注（2-3回/日）を、 術後 3 日目以降に、塩酸リトドリンの内服投与 （3 錠/日）を7日間程度行った。

\section{結 果}

今回の検討期間内では、術前の画像診断により 悪性が疑われ開腹手術となった例はなく、また、 摘出物の病理学的検索により術後に悪性腫瘍と診
断された例もなかった。術前腫瘍マーカーでは、 CA125、CA19-9、AFPで異常值を認めた例があ った（図 1 )。CA125とAFPの高值例においても、 妊娠時の変動の範囲内にあり、画像上も良性腫瘍 と考えられたこと、また、CA19-9高值例では画 像上、皮様囊胞腫の可能性が高いと考えられたこ とから腹腔鏡下手術を施行した。

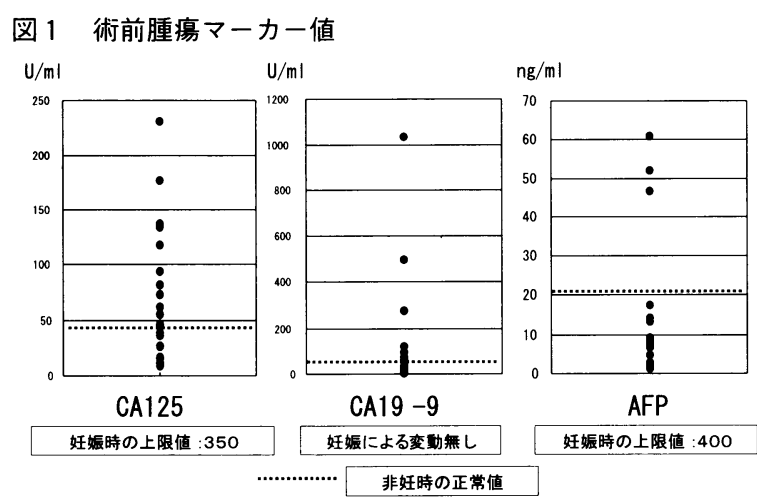

手術を行った週数は、茎捻転のために緊急手術 を行った槳液性囊胞腺腫の 1 例で9週であったが、 その他の症例では、11週：1例、12週： 7 例、13 週：8例、14週：4例、15週：2 例、16週：2例 であった（表 1 、図 2 ）。15週と16週の症例では、 初診時期が遅く、また、16週で手術となった 1 例 では、初診時妊娠14週であったが、糖尿病を合併 していたため、そのコントロールに時間がかかり、 手術の時期が遅くなってしまった。

\section{図 2 手術時の妊娠週数}

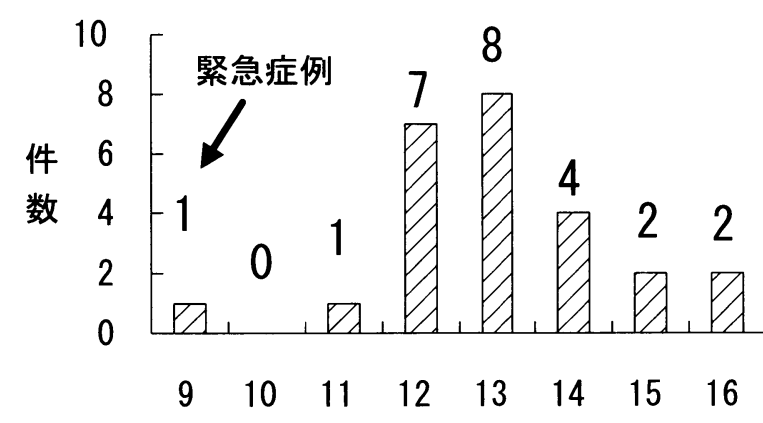

手術所要時間は（図 3 )、33-118分（平均59分） であった。妊娠12週で、手術時間が長い 2 症例が みられた。118分を要した症例 3 は、癒着を伴う 皮様襄胞腫症例であり、その剥離と術中囊腫破綻 图 3 手術時の妊娠週数と手術所要時間

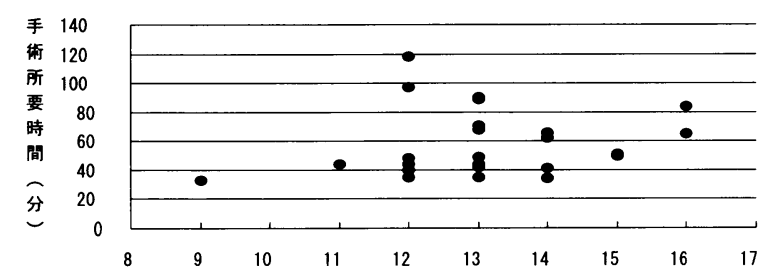


表 1 妊娠中に腹腔鏡下手術を施行した卵巣腫瘍25症例

\begin{tabular}{|c|c|c|c|c|c|c|c|c|}
\hline $\begin{array}{l}\text { 症 } \\
\text { 例 }\end{array}$ & \begin{tabular}{|l|} 
年 \\
齢 \\
\end{tabular} & $\begin{array}{l}\text { 初産/ } \\
\text { 経産 }\end{array}$ & $\begin{array}{l}\text { 手術時の } \\
\text { 妊娠週数 }\end{array}$ & 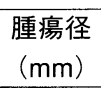 & 手術術式 & 病理組織診断 & \begin{tabular}{|l|} 
術後入 \\
院日数 \\
\end{tabular} & 合併症あるいは特記事項 \\
\hline 1 & 26 & 初産 & 13 & 96 & 付属器摘出術 & 皮様囊胞腫 & 12 & - \\
\hline 2 & 32 & 経産 & 14 & 86 & 付属器摘出術 & 皮様囊胞腫 & 10 & - \\
\hline 3 & 30 & 経産 & 12 & 60 & 付属器摘出術 & 皮様囊胞腫 & 14 & 内容漏出による化学的腹膜炎 \\
\hline 4 & 26 & 経産 & 14 & 82 & 卵巣腫瘍摘出術 & 皮様囊胞腫 & 10 & - \\
\hline 5 & 37 & 経産 & 16 & 82 & 付属器摘出術 & 皮様囊胞腫 & 10 & 糖尿病合併 \\
\hline 6 & 30 & 経産 & 15 & 69 & 付属器摘出術 & 皮様囊胞腫 & 10 & 彺管無力症ありシロッカー縫縮術併施 \\
\hline 7 & 33 & 初産 & 12 & 200 & 卵巣腫瘍摘出術 & 漿液性輁胞腺腫 & 11 & - \\
\hline 8 & 28 & 初産 & 13 & 68 & 卵巣腫瘍摘出術 & 皮様囊胞腫 & 14 & 10年前に皮様囊腫で左付属器摘出術+右囊腫核出術 \\
\hline 9 & 25 & 初産 & 16 & 99 & 卵巣腫瘍摘出術 & 粘液性囊胞腺腫 & 10 & - \\
\hline 10 & 22 & 初産 & 9 & 50 & 卵巣腫瘍摘出術 & 漿液性囊胞腺腫 & 19 & 茎捻転にて緊急手術、術後黄体サポート \\
\hline 11 & 24 & 初産 & 13 & 99 & 卵巣腫瘍摘出術 & 皮様囊胞腫 & 13 & - \\
\hline 12 & 27 & 初産 & 13 & 116 & 卵巣腫瘍摘出術 & 粘液性襄胞腺腫 & 9 & - \\
\hline 13 & 29 & 経産 & 13 & 48 & 付属器摘出術 & 皮様囊胞腫 & 6 & - \\
\hline 14 & 18 & 初産 & 14 & 67 & 卵巣腫瘍摘出術 & 皮様囊胞腫 & 8 & 9週で双胎一児死亡後 \\
\hline 15 & 28 & 経産 & 12 & 93 & 卵巣腫瘍摘出術 & 漿液性囊胞腺腫 & 6 & - \\
\hline 16 & 30 & 初産 & 13 & $\begin{array}{l}76 \text { (右) } \\
64 \text { (左) }\end{array}$ & 卵巣腫瘍摘出術 & 皮様囊胞腫 & 6 & - \\
\hline 17 & 25 & 初産 & 12 & 76 & 卵巣腫瘍摘出術 & 皮様囊胞腫 & 6 & - \\
\hline 18 & 32 & 経産 & 15 & 95 & 付属器摘出術 & 漿液性襄胞腺腫 & 4 & - \\
\hline 19 & 27 & 初産 & 11 & 131 & 付属器摘出術 & 漿液性囊胞腺腫 & 5 & - \\
\hline 20 & 27 & 経産 & 13 & 65 & 卵巣腫瘍摘出術 & 漿液性囊胞腺腫 & 6 & - \\
\hline 21 & 29 & 初産 & 13 & 88 & 卵巣腫瘍摘出術 & 皮様囊胞腫 & 4 & - \\
\hline 22 & 35 & 初産 & 12 & 95 & 卵巣腫瘍摘出術 & 皮様囊胞腫 & 4 & - \\
\hline 23 & 33 & 経産 & 14 & 71 & 卵巣腫瘍摘出術 & 皮様囊胞腫 & 5 & 初回娃娠時に茎捻転で緊急開腹一異腫核出術 \\
\hline 24 & 26 & 初産 & 12 & 72 & 卵巣腫瘍摘出術 & 皮様襄胞腫 & 5 & \\
\hline 25 & 26 & 初産 & 12 & 68 & 卵巣腫瘍摘出術 & 皮様震胞腫 & 4 & \\
\hline
\end{tabular}

図 4 妊娠合併卵巣腫瘍の術後病理診断

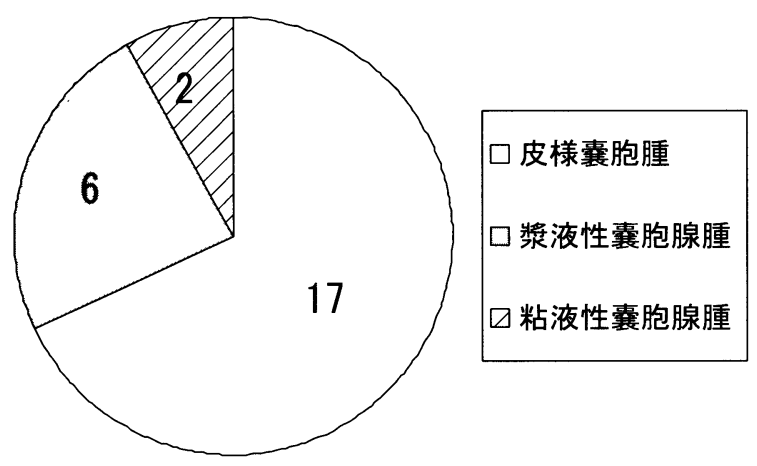

による内容漏出に対しての洗浄に時間を要した。 また、手術時間が97分となった症例7では、摘出 重量2550 g の巨大漿液性襄胞腺腫であり体腔外 の誘導に時間を要した。

25例の術後病理診断は皮様囊胞腫17例、漿液性 囊胞腺腫 6 例、粘液性襄胞腺腫 2 例であった（図 $4) 。 8$ 例において付属器摘出術、17例において 体外法による震腫核出術を行った（表 1 ）。付属 器摘出術となった理由は、経産婦で本人希望によ るものが 6 例、正常卵巣と囊腫壁の分離が出来な いために、囊腫核出術が困難なものが 2 例であっ た。摘出腫瘍重量は、15-2550 g であった。

手術前後の合併症あるいは特記事項（表 1) と しては、症例 3 において、癒着を伴う皮様囊腫の
剥離の際に術中破綻による内容の漏出を起こし た。十分に洗浄したにもかかわらず、化学性腹膜 炎による腹痛と術後 7 日間の38度台の発熱の持続 を認めた。抗生剤投与の延長により保存的に軽快 し、その後の妊娠経過には異常を認めなかった。 症例 6 においては、頝管無力症の合併が有り、シ ロッカー頝管綘縮術を併施した。症例 8 では、10 年前に開腹手術による左付属器摘出術および右囊 腫核出術を当科で受けた後の右側再発例で、今回 は再度、右の囊腫核出術を行った。本症例では、 今回の術後の正常経胵分娩を経て、2人目も自然 妊娠後に正常経腟分娩となっている。症例10では、 漿液性震胞腺腫茎捻転のため、妊娠 9 週で緊急に 囊腫核出術を行った。囊腫の核出側に黄体があり、 手術操作により一部黄体組織が失われた可能性が あったために術後黄体サポートを 2 週間程度行っ た後に退院した。その後の妊娠経過には異常を認 めず、紹介元の医院において正常経胵分婏となっ ている。症例23においては、前回の妊娠時に右皮 様囊腫の茥捻転のために、他院で開腹手術による 囊腫核出を受けており、今回は、左側の皮様囊腫 があり、腹腔鏡下手術を希望して妊娠14週で紹介 された。前回の創部に大網癒着を認めたためハー モニックスカルペルにて癒着を剥離した後に体外 
法により囊腫核出術を行い、術後経過は良好である。 術後入院日数は（表 1 )、初期の頃は、手術又 トレスによる術後の子宮収縮に対する危惧もあ り、やや長めの子宮収縮抑制剂投与とベッド上で の安静を予防的に行ったため、10-14日前後と長 めであったが、特に、流産等の問題症例が認めら れなかったことから、術後入院日数を徐々に短縮 していき、最近は4-6日目に退院としている。現 在、妊娠継続中の症例を含めて、術後の妊娠分婏 経過に異常を認めた例はなかった。

\section{考案ならびに結語}

1997年 5 月から 2002年10月までに、当科におい て経験した25例の妊娠合併卵巣腫瘍につき、その 適応、手術時の妊娠週数、術中術後の経過につき 報告した。

妊娠に卵巣腫瘍が合併する頻度は、日本では 0.21-1.21\%であり、その中での悪性卵巣腫瘍の占 める割合は、2-5\%と低いことが報告されてい $3^{13.14)}$ 。また、卵巣腫瘍の中での内訳は、皮様囊 胞腫が30\%、槳液性腺腫が $30 \%$ 、粘液性腺腫が $10 \%$ と言われている。今回の報告では、皮様囊胞 腫の頻度が25例中15例（65.2\%） と高かったが、 これは、当院では紹介患者の比率が高いために、 漿液性囊胞腺腫が、黄体囊胞との鑑別の上で、紹 介元の医療機関で経過観察となっている場合が多 いことによるのかもしれない。

妊娠が卵巣腫瘍に与える影響としては、妊娠の 進行に伴い、子宮が増大するために発症する卵巣 腫瘍の茥捻転や破裂がある。茎捻転は妊娠3-5 ケ 月、分婏直後や産裖期に起こりやすく、破裂は分 婏時に起こりやすいと言われている。逆に、卵巣 腫瘍が母児に与える影響としては、腫瘍の移動や 圧迫により妊娠子宮が機械的な刺激を受けること や茎捻転や破裂による腹膜刺激症状のために誘発 される流早産がある。更に、分婏時には児の下降 障害により帝王切開術が必要となることもある。 今回の検討期間中に、当科へ妊娠 20 週以降に紹介 あるいは緊急母体搬送された症例中、卵巣腫瘍が ダグラス窩に陥頓しているために、児頭下降不全 があり、帝王切開術を要した例が 9 例認められた。 この内の 1 例の経過を紹介する。23歳の初妊初産 婦が、妊娠 25 週で急激な腹痛と発熱のために、当 科へ母体搬送された。皮様囊腫の捻転あるいは破 裂と診断したが、塩酸リトドリンの点滴と抗生剤 投与により保存的に軽快した。その後、37週で、 皮様囊腫がダグラス窩に陥頓しており児頭下降が
みられず、帝王切開術と同時に付属器摘出術を行 った。ダグラス窩には、可動性のない強固な癒着 を伴う皮様囊腫が存在し、25週で、揄転した後に、 陳旧性となっていたものと考えられた。本症例で は、その後、自然妊娠し経胵分婏（VBAC）とな っている。従って、本例においては、初回妊娠時 に腫瘍の摘出術が適切に行われていれば、その後 の妊娠中のトラブルの発生や帝王切開術が回避で きたものと考えられる。一方、今回、当科におい て腹腔鏡下手術を行った症例では、妊娠中あるい は分婏時に異常を認めた例は認められなかったこ とから、妊娠合併卵巣腫瘍に対しては、妊娠週数 等の条件が合えば、積極的な摘出が、妊娠中のト ラブルを避ける上で重要と思われた。

妊娠合併卵巣腫瘍の診断は、通常、内診と超音 波断層法により行われる。経腟超音波断層法等の 診断技術の進歩により、早期に妊娠に合併した付 属器腫瘤の発見される頻度が増加してきている。 しかしながら、発見されるものは妊娠10-12週頃 までに自然消退することの多い黄体囊胞の比率が 高く、腹痛等の症状のない場合には、継週的に超 音波検查を反復して行い、真性腫瘍との鑑別に努 め、手術療法が過剩とならないように努めなけれ ばならない。補助的な検査としては、腫瘍マーカ 一の測定も行うが、良性腫瘍であっても上昇して いることや妊娠に伴い腫瘍マーカー値が変動する 点に注意する必要がある ${ }^{13)}$ 。コア蛋白関連マーカ 一であるCA125は、卵巣癌の診断や治療効果の指 標として汎用されているが、妊娠により変動する ことが知られている ${ }^{17)}$ 。妊娠初期には、非妊時に 比して上昇し、中期以降は減少していく。妊娠中 の母体血中の生理的上限は200-350U/mlで、その ピークとなる時期は妊娠 2 ケ月である。今回の検 討例中でも、粘液性囊胞腺腫の 1 例でCA 125 が $231 \mathrm{U} / \mathrm{ml}$ を示す 1 例があったが、画像上は良性と 判断し腹腔鏡下手術を行った。基幹糖鎖関連マー カーであるCA19-9については、全妊娠期間を通 じて、妊娠による変動はみられないが18)、皮様囊 胞腫などの良性卵巣腫瘍において30-50\%の偽陽 性率を示すため、マーカー值のみで良性悪性の診 断をつけることは困難である。今回の検討でも、 $1036 \mathrm{U} / \mathrm{ml}$ という高值を示す皮様囊腫の 1 例が認 められた。術前の画像診断上、皮様囊胞腫と考え られたので、体外法による襄腫核出術を行い、術 後病理診断も皮様囊胞腫であり、その後の経過に も異常を認めていない。癌胎児蛋白である AFP は、妊娠前期でほぼ正常域にあるが、14-15週頃 
より上昇し始め、そのピークは32週頃にあり、生 理的な上限值は300-400ng/ $\mathrm{ml}$ である ${ }^{18)}$ 。今回、皮 様囊腫の 2 例でそれぞれ、61.0、52.1ng/ $\mathrm{ml}$ 、漿 液性腺腫の 1 例で $46.7 \mathrm{ng} / \mathrm{ml}$ と軽度上昇を認めた が、妊娠時の生理的な上昇の範囲内であり、画像 上は良性と思われたので腹腔鏡下手術で対応し た。当科では、超音波断層法やマーカー検査等で、 判断に迷う場合のみに、MRIによる画像診断を追 加するようにしている。MRIは、児に対する危険 性は低いと考えられてはいるが19)、超音波画像の みで診断が確定できそうな場合には、前述のよう に、妊娠合併卵巣腫瘍においては、その殆どが良 性腫瘍であり、悪性腫瘍の頻度は低いこともあり、 MRIを必要以上に行わないようにしている。

手術施行時期に関しては、腹腔鏡下における視 野確保という点から、開腹手術で推奨されている 妊娠14-15週20)よりは、やや早い時期に設定した 方が良いと考えている。内分必学的には、妊娠黄 体の絶対必要期間は妊娠 8 週までであり、妊娠 10 週以降は黄体ホルモンは主に胎盤で分泌されるよ うになることから、手術施行時期は妊娠10週以降 が望ましい。また、麻酔や術後に使用する薬剤の 胎児に対する影響を考慮すると手術施行時期は胎 児の主要器官形成時期を過ぎた妊娠 12 週以降が望 ましい。更に、黄体囊胞の除外診断時期を考える と、総合的に判断される手術施行時期は妊娠 12 週 前後であろう。

術中の注意点としては、出来るだけ子宮収縮を 生じさせないように、妊娠子宮を愛護的に取り扱 う必要がある。また、術後の流産発症の予防のた めに術前から術後にかけて子宮収縮抑制剤を投与 を当科では、ルチーンに行っている。更に、術中、 手術操作による刺激のために子宮収縮が誘発され た場合には、適時、子宮収縮抑制剤を使用してい る。妊娠合併卵巣腫場に対する腹腔鏡下手術は、 14週以降では、子宮腫大により視野が著しく不良 となり、視野確保のためにどうしても子宮圧排を 行う必要が生じることから、上で述べた 12 週前後 での手術が、子宮に対する負担を可級的に少なく するという観点からも、望ましいと思われた。

今回の検討では、手術適応、特に、手術を行う 妊娠週数を慎重に決め、全身麻酔下に皮下鋼線吊 り上げ法により腹腔鏡下手術を行えば、特に妊娠 経過への悪影響はみられず、母児ともに安全で低 侵襲であると考えられた。

本論文の要旨は、第 42 回日本産科婦人科内視鏡 学会（東京）［演題番号：78］において発表した。

\section{文献}

1) Fatum M, Rojansky N.: Laparoscopic surgery during pregnancy. Obstet Gyneol Surv 56:50, 2001.

2 ) Gouldman JW, et al:: Laparoscopic cholecystectomy in pregnancy. Am Surg 64:93, 1998.

3 ) Andreoli $\mathrm{M}$, et al.: Laparoscopic surgery during pregnancy. J Am Assoc Gynecol Laparosc 6:229, 1999.

4 ) Vilos GA.: Laparoscopic salpingo-oophorectomy during pregnancy. J Am Assoc Gynecol Laparosc 2:463, 1995.

5 ) Neiswender LL, Toub DB.: Laparoscopic excision of pelvic masses during pregnancy. J Am Assoc Gynecol Laparosc 4:269, 1997.

6 ）伊藤誠、他：卵巣腫瘍合併妊娠症例に対する腹壁 吊り上げ法による腹腔鏡下腫瘍摘出術、産婦人科 治療、75：95、1997.

7 ) Tanaka H, et al..: Gasless laparoscopy under epidural anesthesia for adnexal cysts during pregnancy. J Reprod Med 44:929, 1999.

8 ) Akira S, et al..: Gasless laparoscopic ovarian cystectomy during pregnancy. Am J Obstet Gynecol 180:554, 1999.

9 ）塚原慎一郎、他：腹腔鏡下手術を行った卵巣腫瘍 合併妊娠8症例の検討、臨床婦人科産科、 $53: 1215$ 、 1999.

10) Moore RD, Smith WG.: Laparoscopic management of adnexal masses in pregnant women. J Reprod Med 44:97, 1999.

11）宮井健太郎、他：卵巣腫瘍合併妊娠に対する手術 療法、日産婦内視鏡会誌、16：100、2000.

12) Abu-Musa A, et al..: Laparoscopic unwinding and cystectomy of twisted dermoid cyst during second trimester of pregnancy. J Am Assoc Gynecol Laparosc 8:456,2001.

13）筒井章夫：妊娠と卵巣腫瘍合併の取り扱い方 そ の1、日産婦誌、44：N-31、1992

14）筒井章夫：妊娠と卵巣腫瘍合併の取り扱い方 そ の2、日産婦誌、44：N-51、1992

15）竹田明宏、他：当科における卵巣腫瘍に対する腹 腔鏡下手術施行症例の検討、日産婦内視鏡会誌、 $14: 71 、 1999$

16）竹田明宏、他：当科における婦人科腹腔鏡下手術 施行症例の検討、産と婦、64：1009、1997

17）鈴木光明、他：卵巣癌関連糖蛋白抗原CA125に関 する研究。( II ) 正常妊婦血清CA125值、臨床病理、 $33: 73 、 1985$

18）菅原照夫、他：婦人科疾患と関係のある腫瘍マー カー值の妊娠、分婏㧍よび産裖における変動につ いて、日産婦誌、43：145、1991

19) Kier $\mathrm{R}$, et al.:Pelvic masses in pregnancy: $M R$ imaging. Radiology 176:709, 1990

20）廣田譲、他：卵巣腫瘍を合併した妊婦の管理、産 婦治療、61：393、1990 